\title{
UPAYA MENINGKATKAN HASIL BELAJAR BIOLOGI SISWA MELALUI PENDEKATAN KONTEKSTUAL DENGAN MEDIA POWERPOINT
}

\author{
Jhonas Dongoran \\ Surel:bronikaseptiani@yahoo.com
}

\begin{abstract}
This study aims to determine whether learning through a contextual approach with PowerPoint media can improve student biology learning outcomes on the subject of the Ecosystem. The study was conducted at Sibabangun Public High School 1. The population in this study were all senior students X SMA 1 Sibabangun which consisted of 3 classes. From the population a sample of 2 classes was determined, namely the experimental class and the control class. Both classes were given different treatment, the experimental class was given teaching through a contextual approach with PowerPoint media, while the control class was given teaching through the lecture method. From the data analysis for the experimental class, post-tests were obtained $(83.56 \pm 7.54)$. In the control class, post-test was obtained (68.93 \pm 7.82$)$. Both data are normally distributed. From the hypothesis testing obtained thitung $=3.419$ and at the significance level $\alpha=0.05$ with $d k=58$ obtained t table $=1.574$. Because tcount $>$ ttable then tcount is in the reception area Ha. This means that learning through a contextual approach with PowerPoint media is better than learning through the lecture method. Learning through contextual approaches with PowerPoint media can improve student biology learning outcomes by $60.31 \%$.
\end{abstract}

Keywords: Learning Outcomes, Contextual, PowerPoint

\begin{abstract}
ABSTRAK
Penelitian ini bertujuan untuk mengetahui apakah pembelajaran melalui pendekatan kontekstual dengan media PowerPoint dapat meningkatkan hasil belajar biologi siswa pada pokok bahasan Ekosistem. Penelitian dilakukan di SMA Negeri 1 Sibabangun. Populasi dalam penelitian ini adalah seluruh siswa kelaa X SMA Negeri 1 Sibabangun yang terdiri dari 3 kelas. Dari populasi ditetapkan sampel sebanyak 2 kelas yaitu kelas eksperimen dan kelas kontrol. Kedua kelas diberikan perlakuan yang berbeda, kelas eksperimen diberikan pengajaran melalui pendekatan kontekstual dengan media PowerPoint, sedangkan kelas kontrol diberikan pengajaran melalui metode ceramah. Dari analisa data untuk kelas eksperimen diperoleh post-tes $(83,56 \pm 7,54)$. Pada kelas kontrol diperoleh post-tes $(68,93 \pm 7,82)$. Kedua data tersebut berdistribusi normal. Dari pengujian hipotesis diperoleh $\mathrm{t}_{\text {hitung }}=$ 3,419 dan pada taraf singnifikansi $\alpha=0,05$ dengan $\mathrm{dk}=58$ diperoleh $\mathrm{t}_{\text {tabel }}=$ 1,574. Karena $t_{\text {hitung }}>t_{\text {tabel }}$ maka $t_{\text {hitung }}$ berada pada daerah penerimaan Ha. Hal ini berarti bahwa pembelajaran melalui pendekatan kontekstual dengan media PowerPoint lebih baik daripada pembelajaran melalui metode ceramah. Pembelajaran melalui pendekatan kontekstual dengan media PowerPoint dapat meningkatkan hasil belajar biologi siswa sebesar 60,31\%.
\end{abstract}

Kata Kunci : Hasil Belajar, Kontekstual, PowerPoint 
Jhonas Dongoran: Upaya Meningkatkan Hasil Belajar...

\section{PENDAHULUAN}

Rendahnya pendidikan sebagian besar diakibatkan karena kurang efektifnya proses belajar-mengajar. Dalam sistem pembelajaran, guru sering menerapkan pembelajaran yang bersifat teoritik yang mengakibatkan sebagian besar siswa tidak dapat mengkaitkan apa yang dipelajari dengan kehidupan sehari-hari. Kenyataan ini membuat siswa sering hanya menghapal teori atau konsep pelajaran tanpa mengetahui aplikasi dari apa yang dipelajari.

Di era perkembangan IPTEK saat ini, media pembelajaran merupakan hal yang sudah selayaknya digunakan guru dalam menyampaikan materi pelajaran. Banyak sekolah terutama yang terletak di perkotaan sudah dilengkapi dengan media pembelajaran salah satunya media komputer. Media komputer merupakan salah satu yang termasuk media penyaji yang dapat difungsikan untuk menyampaikan materi. PowerPoint merupakan salah satu program komputer yang dapat dijadikan sebagai media menyampaikan materi agar pembelajaran dapat berlangsung lebih efektif. Namum kenyataan di lapangan menunjukkan bahwa penggunaan media terutama media komputer sering hanya mempercepat penyampaian materi saja tetapi belum dapat meningkatkan prestasi belajar siswa. Hal ini diakibatkan karena guru belum dapat mengajak siswa mengalami langsung pelajaran yang disampaikan.

Pembelajaran Kontekstual (Contextual Teaching and Learning/CTL) adalah sebuah proses pembelajaran yang bersifat menyeluruh atau holistik. Pada pembelajaran kontekstual, siswa dimotivasi sehingga mereka dapat memahami makna bahan pelajaran sesuai konteks kehidupan mereka sehari-hari (konteks pribadi, sosial, dan kultural). Dengan pendekatan kontekstual, siswa akan mempunyai pengetahuan dan keterampilan yang dapat diterapkan (ditransfer) dari satu permasalahan atau konteks ke permasalahan ke konteks lainnya.

Pada pendekatan kontekstual, guru mencoba menghadirkan situasi dunia nyata ke dalam kelas. Siswa diajak untuk menemukan dan membentuk hubungan-hubungan antar pengetahuan, kemudian juga bagaimana penerapannya dalam kehidupan mereka sebagai anggota keluarga dan masyarakat. Ada lima strategi pembelajaran kontekstual (contextual teaching and learning), yaitu relating (menghubungkan), experiencing (mengalami), applying (menerapkan), cooperating (bekerja sama), dan transferring (mentransfer). Melalui kelima strategi ini nantinya diharapkan siswa akan mencapai standar kompetensi yang diharapkan secara maksimal.

Pendekatan dan pembelajaran kontekstual terkait erat dengan pembelajaran aktif (active learning). Dalam pembelajaran kontekstual, 
dalam hubungannya dengan pembelajaran aktif, maka siswa harus dapat diajak untuk membangun sendiri pengetahuan, konstruktivisme atau (constructivism), aktif bertanya (questioning), aktif untuk menemukan pengetahuannya atau konsep-konsep yang sedang dipelajari (inquiry), bekerja bersama dan belajar bersama dalam suatu masyarakat belajar (learning community), melakukan pemodelan (modeling), dan menerapkan penilaian otentik (authentic assessment).

Ekosistem merupakan salah satu pokok bahasan dalam ilmu biologi yang di dalamnya terdapat banyak konsep dasar IPA. Siswa sering kesulitan dalam mempelajari materi ini karena siswa sering dituntut untuk menghapal materi. Padahal materi Ekosistem ini merupakan materi yang sangat erat kaitannya dengan kehidupan seharihari. Ekosistem ini merupakan materi yang sangat cocok disampaikan dengan menggunakan pendekatan kontekstual agar konsep yang dipelajari itu bukan hanya dihapal tetapi dapat secara langsung dikaitkan dengan contoh-contoh yang terdapat dalam kehidupan sehari-hari dan untuk mengefektifkan penyampaikan dapat digunakan media PowerPoint.

SMA Negeri 1 Sibabangun merupakan salah satu SMA Negeri yang telah dilengkapi dengan media pembelajaran terutama media komputer. Guru bidang studi sudah sering menggunakan media di dalam menyampaikan materi pelajaran. Penggunaan media ini diakui sangat membantu dalam mempercepat penyampaian materi tetapi pengetahuan siswa tentang materi yang disampaikan belum semaksimal yang diharapkan. Hal ini diakibatkan karena media yang digunakan guru cenderung hanya sebagai alat bantu dalam mempercepat penyampaian materi tanpa menuntut keaktifan siswa sehingga siswa cenderung pasif dan hanya sebagai penerima informasi saja. Adapun tujuan dalam penelitian ini adalah untuk mengetahui: Apakah ada pengaruh yang signifikan pembelajaran melalui pendekatan kontekstual dengan media PowerPoint terhadap peningkatan hasil belajar siswa dan Apakah pembelajaran melalui pendekatan kontekstual dengan media PowerPoint efektif dilaksanakan pada pokok bahasan Ekosistem.

\section{METODE PENELITIAN}

Penelitian dilaksanakan di kelas X SMA Negeri 1 Sibabangun Kabupaten Tapanuli Tengah. Populasi penelitian ini adalah seluruh siswa kelas $\mathrm{X}$ SMA Negeri 1 Sibabangun yang terdiri dari 3 kelas dan masing-masing kelas terdiri dari rata-rata 30 orang siswa. Sampel diambil secara acak yaitu sebanyak 2 kelas yang dijadikan sebagai kelas eksperimen dan kelas kontrol. Penentuan kelas dipilih dengan menggunakan teknik pengambilan sampel secara acak. Kelas eksperimen yang menggunakan 
Jhonas Dongoran: Upaya Meningkatkan Hasil Belajar...

pembelajaran dengan pendekatan kontekstual dengan media PowerPoint dan kelas kontrol menggunakan pembelajaran ceramah. Dalam penelitian ini digunakan dua perangkat pembelajaran dan instrumen penelitian. Perangkat pembelajaran ini yang disusun merupakan perangkat pembelajaran yang mengarah kepada pembelajaran pendekatan kontekstual dengan media PowerPoint dan pembelajaran ceramah. Sedangkan instrumen penelitian umtuk memperoleh data hasil belajar siswa. Dalam penelitian ini, untuk memperoleh data digunakan instrumen tes dalam bentuk objektif. Sebelum digunakan terlebih dahulu diuji.

Hipotesis yang diuji adalah :

$$
\begin{aligned}
& \text { Ho }: \mu_{1} \leq \mu_{2} \\
& \text { Ha }: \mu_{1}>\mu_{2}
\end{aligned}
$$

Setelah data berdistribusi normal dan varians homogen maka hipotesis dalam penelitian ini dilakukan dengan menggunakan uji-t satu pihak dengan t-test menggunakan rumus:

$$
\mathrm{t}_{\text {hitung }}=\frac{\overline{\mathrm{x}}_{1}-\overline{\mathrm{x}}_{2}}{\sqrt[\mathrm{s}]{\frac{1}{\mathrm{n}_{1}}}+\frac{1}{\mathrm{n}_{2}}}
$$

Persen (\%) peningkatan hasil belajar siswa dapat dihitung dengan menggunakan rumus:

$\%$ peningkatan hasil belajar $=\frac{X_{p o s t}-X_{p r e}}{X_{p r e}} \times 100 \%$

\section{HASIL PENELITIAN DAN PEMBAHASAN}

Instrumen tes yang digunakan sebagai post-tes sama dengan instrumen yang digunakan pada saat pre-tes yaitu soal pilihan berganda sebanyak 20 soal dengan urutan yang telah diacak. Post-tes diberikan kepada kelas eksperimen setelah diberikan pembelajaran melalui pendekatan kontekstual dengan media PowerPoint dan kelas kontrol setelah diberikan pengajaran dengan metode ceramah dan. Secara ringkas hasil post-tes.

Uji hipotesis dilakukan untuk mengetahui apakah hipotesis alternatif (Ha) diterima atau ditolak. Uji hipotesis yang dilakukan adalah uji t pada taraf signifikansi $\alpha=0,05$, dengan kriteria pengujian terima $\mathrm{Ha}$ jika thitung $>t_{\text {tabel. }}$ Dari hasil perhitungan uji hipotesis diperoleh data pada Tabel 1.

Tabel 1. Uji Hipotesis

\begin{tabular}{ccccc}
\hline Kelompok & Data & thitung & $\mathrm{t}_{\text {tabel }}$ & Ket. \\
\hline Eksperimen & 83,56 & & & \\
\cline { 2 - 2 } & $\mathrm{SD}=$ & & & \\
& 6,54 & & 1,574 & Ha \\
& 6,419 & & diterima \\
\cline { 2 - 2 } Kontrol & 68,93 & & & \\
\cline { 2 - 2 } & $\mathrm{SD}=$ & & & \\
& 7,82 & & & \\
\hline
\end{tabular}

Berdasarkan data diperoleh bahwa $t_{\text {hitung }}>\mathrm{t}_{\text {tabel }}(3,419>1,574$. Karena thitung berada pada daerah kritis maka ha diterima dan ho ditolak.

\section{Pembahasan}

Hasil analisa data penelitian menunjukkan bahwa data yang 
diperoleh terdistribusi secara normal dan sampel berasal dari populasi yang homogen. Dari hasil perhitungan uji hipotesis diperolah data bahwa $t_{\text {hitung }}=3,419$ sedangkan $t_{\text {tabel }}$ pada taraf signifikansi 0,05 dengan $\mathrm{dk}=58$ diperoleh $\mathrm{t}_{\text {tabel }}=$ 1,574 sehingga $t_{\text {hitung }}>t_{\text {tabel }}$. Karena $t_{\text {hitung }}>t_{\text {tabel }}$ (berada pada daerah kritis) maka dapat disimpulkan bahwa Ha diterima dan Ho ditolak. Dengan demikian hasil belajar biologi siswa pada pokok bahasan Ekosistem yang diberi pembelajaran melalui pendekatan kontekstual dengan media PowerPoint lebih baik dari hasil belajar biologi siswa yang diberi pembelajaan dengan metode ceramah. Hal ini dapat dilihat dari perbedaan rata-rata nilai akhir siswa pada kelas ekperimen dan kelas kontrol. Kelas eksperimen mempunyai nilai rata-rata 83,56 dengan simpangan baku 6,54 sedangkan kelas kontrol mempunyai nilai rata-rata 8,93 dengan simpangan baku 7,82. Dari perhitungan diperolah bahwa pembelajaran melalui pendekatan kontekstual dengan media PowerPoint pada pokok bahasan Ekosistem dapat meningkatkan hasil belajar siwa sebesar $60,31 \%$. Hal ini dapat dilihat dari berbagai aspek yaitu:

a. Dalam proses pembelajaran siswa dituntut untuk selalu aktif baik dalam kelompok atau dalam kelas. Setiap kondisi dalam pembelajaran menuntut siswa untuk tidak hanya menerima pelajaran tetapi harus dapat memberikan sumbangan pemikiran dalam setiap materi yang diajarkan guru. Hal ini akan melatih siswa mengemukakan ide-idenya dan memberikan motivasi agar siswa aktif untuk mempelajari materi sebelum tatap muka di kelas.

b. Dalam proses belajar-mengajar, guru selalu menuntun siswa untuk selalu mengaitkan apa yang dipelajari dengan kejadiankejadian yang terdapat dalam lingkungan sekitar siswa. Hal ini dapat membantu siswa dalam meningkatkan daya ingat terhadap materi yang dipelajari sekaligus sebagai nilai tambah bagi siswa agar pengetahuan yang dimilikinya tidak bersifat abstrak melainkan bersifat konkrit.

c. Dalam proses belajar-mengajar, siswa mempunyai pemahaman dan ketrampilan yang dibangun atas dasar pemikirannya sendiri akan konsep yang dipelajari bukan hanya sekedar menghapal konsep yang diberikan guru atau konsep yang terdapat dalam buku penuntun.

Proses belajar mengajar tidak terbatas hanya terjadi dalam lingkungan kelas dan dalam pengawasan guru tetapi dapat berlangsung di luar kelas dan siswa bebas mengekspresikan segala. denya dalam karya yang akan dikumpulkan. Hal ini akan memberikan kesempatan kepada siswa untuk jeli melihat apa-apa 
Jhonas Dongoran: Upaya Meningkatkan Hasil Belajar...

yang terjadi dalam lingkungan dan mengaitkannya dengan konsep yang dipelajari.

Sardiman

(2007), mengatakan bahwa pembelajaran dengan pendekatan kontektual membantu mengaitkan materi ajar dengan situasi dunia nyata siswa yang mendorong siswa untuk membuat hubungan antara pengetahuan yang dipelajarinya dengan penerapannya dalam kehidupan nyata. Belajar itu tidak lagi hanya sekedar menghafal faktafakta yang ada. Kenyataan ini membantu siswa untuk memahami pelajaran yang diterima sehingga semakin lama mengendap dalam ingatan siswa. Siswa juga semakin aktif dalam kegiatan belajarmengajar karena siswa diberi kebebasan untuk aktif bertanya dan aktif juga menjawab. Siswa semakin semangat dan termotivasi dalam kegiatan pembelajaran karena siswa dituntun untuk saling membatu dalam kelompok belajar agar dapat bersaing dengan kelompok lain dan ada kalanya antar kelompok yang bersaing juga saling membantu dalam mengikuti pelajaran.

$$
\text { Penggunaan }
$$

media

PowerPoint semakin membantu terlaksananya proses belajarmengajar. Materi dapat dilihat langsung oleh siswa dengan contohcontoh dalam kehidupan dan sekaligus dapat dibimbing untuk menemukan sendiri pengetahuannya. Soal-soal yang didiskusikan siswa juga semakin cepat diberikan. Dengan adanya media PowerPoint

ini guru semakin $r$ cepat
mengkoordinir siswa dan siswa
semakin aktif.
Pembelajaran
pendekatan kontekstual dan media
PowerPoint merupakan salah satu
penggabungan yang tepat. Di satu
sisi PowerPoint mempercepat
penyampaian materi dan disisi lain
pendekatan kontekstual memberikan
solusi walaupun materi disampaikan
dengan cepat tetapi siswa dapat
memahami materi dan dapat
mengkaitkan dengan kehidupan
nyata.

\section{SIMPULAN}

Berdasarkan hasil penelitian dan pembahasan diperoleh kesimpulan sebagai berikut:

a. Hasil belajar biologi siswa melalui pendekatan kontekstual dengan media PowerPoint pada pokok bahasan Ekosistem lebih tinggi dibandingkan dengan hasil belajar biologi siswa yang diberi pembelajaran melalui metode. Hal ini dibuktikan dari uji hipotesis yang menunjukkan bahwa $t_{\text {hitung }}>\mathrm{t}_{\text {tabel }}(3,419>$ 1,574).

b. Pembelajaran melalui pendekatan kontekstual dengan media PowerPoint pada pokok bahasan Ekosistem di kelas X IPA SMA Negeri 1 Sibabangun dapat meningkatkan hasil belajar kimia siswa sebesar 60,31\%.

c. Perbedaan rata-rata hasil belajar untuk kelas eksperimen 83,56 dengan kelas kontrol 68,93 membuktikan bahwa 
pembelajaran melalui pendekatan

kontekstual dengan media PowerPoint efektif digunakan dalam meningkatkan hasil belajar biologi siswa.

\section{DAFTAR RUJUKAN}

Arikunto, S. 2003. Dasar-dasar Evaluasi Pendidikan Edisi Revisi. Jakarta: Bumi Aksara. Arsyad. 2004. Media Pengajaran. Jakarta: Raja Grafindo Persada. Djamarah, S.B dan Aswan, Z. 2006. Strategi Belajar Mengajar. Jakarta: Rineka Cipta.

Debdikbud. 1991. Kamus Umum Bahasa Indonesia. Edisi Ke-2. Jakarta: Balai Pustaka.

Musclish, M. 2007. KTSP Pembelajaran Berbasis Kompetensi dan Kontekstual. Jakarta: Bumi Aksara.

Sanjaya, W. 2006. Pembelajaran dalam Implementasi Kurikulum Berbasis Kompetensi, Kencana. Jakarta: Prenada Media Group.

Sardiman. 2007. Interaksi dan Motivasi Belajar Mengajar. Jakarta: Raja Grafindo Persada. Sudjana. N. 2002. Metode Statistika. Bandung: Penerbit Tarsito.

Usman, H., dan Purnomo, S. A. 2000. Pengantar Statistik. Jakarta: Penerbit Bumi Aksara. 